\title{
The analysis of a diagnostic informativeness of gas dynamic parameters in a marine diesel engine turbocharging system through an entropy function
}

\begin{abstract}
The article presents selected elements of the elaborated diagnostic testing method of marine diesel engine working spaces based on the energetic and spectral-correlation analysis of the course of the pulsating exhaust flow process in the channel powering a turbocharger. The investigations have been worked out within the scope of a realization of the research project No. OT00B02129 funded by the Committee of Scientific Research. Conducting of an analysis of the diagnostic informativeness among the parameters characterizing the observed gas dynamic processes represented an essential methodological question of the project. A mathematical model, enabling simulations of well-known and recognizable engine working spaces failures as well as an entropy functions, as the measure of uncertainty of the set of identified states of the engine unfitness were applied for such a diagnostic purpose. Having evaluated the diagnostic information three diagnostic parameters were selected in the result of experiments of the numerical simulation. Thus, the adequate parameters of a technical state assessment of the marine diesel engine working spaces were chosen while there was no possibility to work out the cylinder indication (to create cylinder indicator diagrams). The conducted simulating investigations represented an introduction to the experimental investigations (to the diagnostic tests) of DETROIT DIESEL and ZVIEZDA engines that had been put into operation on the Polish Navy warships in recent years.
\end{abstract}

Key words: technical diagnostics, marine diesel engines, working spaces, diagnostic informativeness, diagnostic parameters

\section{Analiza informacyjności diagnostycznej parametrów gazodynamicznych w układzie turbodoładowania silnika okrętowego z zastosowaniem funkcji entropii}

\begin{abstract}
W artykule zaprezentowano wybrane elementy metodyki badań diagnostycznych przestrzeni roboczych silnika okrętowego, bazujacej na analizie energetycznej $i$ widmowo-korelacyjnej przebiegu procesu pulsacyjnego przeptywu spalin w kanale zasilajacym turbosprężarkę. Badania realizowano w ramach projektu badawczego nr 0T00B02129 finansowanego ze środków Komitetu Badań Naukowych. Istotnym zagadnieniem metodycznym projektu było przeprowadzenie analizy informacyjności diagnostycznej parametrów charakteryzujacych obserwowane procesy gazodynamiczne. Wykorzystano do tego celu model matematyczny umożliwiający symulację znanych i rozpoznawalnych uszkodzeń elementów przestrzeni roboczych silnika oraz funkcje entropii, jako miary nieokreśloności zbioru identyfikowanych stanów niezdatności. W wyniku eksperymentów symulacji numerycznej wyselekcjonowano trzy parametry diagnostyczne, dla których dokonano oceny wnoszonej informacji diagnostycznej. W ten sposób wytypowano adekwatne parametry oceny stanu technicznego przestrzeni roboczych silnika okrętowego, dla którego nie ma możliwości przeprowadzenia indykowania cylindrów. Przeprowadzone badania symulacyjne byly wstępem do badań eksperymentalnych (testów diagnostycznych) silników typu DETROIT DIESEL $i$ ZVIEZDA wdrożonych w ostatnich latach do eksploatacji na okrętach Marynarki Wojennej RP.

Słowa kluczowe: diagnostyka techniczna, silnik okrętowy, przestrzenie robocze, informacyjność diagnostyczna, parametr diagnostyczny
\end{abstract}

\section{Introduction}

Every marine engine manufacturer defines a set of basic diagnostic parameters possible to be determined by the engine user during its operation at sea. They also establish the tolerance limits within which values of the parameters should be kept during the operation process. The values characterise a functioning quality of an engine and enable the determining of the general its technical condition. An excess of the established limits by any of the diagnostic parameters is a sign of an unacceptable disturbance of the energy processes of the engine, which can lead to its failure.

In the situation its operator should start localising the defect and make efforts to gain detailed information about the technical state of each its functional modules. Therefore

\section{Wstęp}

Wszyscy producenci okrętowych silników spalinowych określają zbiór podstawowych parametrów diagnostycznych możliwych do wyznaczenia przez użytkownika na okręcie. Precyzują również granice tolerancji, w których mogą znajdować się ich wartości podczas eksploatacji. Parametry te charakteryzuja jakość funkcjonowania silnika i pozwalają na określenie jego ogólnego stanu technicznego. Wyjście wartości któregokolwiek z wyznaczonych parametrów poza ustalone granice sygnalizuje niedopuszczalne zakłócenie procesów energetycznych realizowanych w silniku, grożące jego awarią.

W takiej sytuacji użytkownik powinien przystąpić do lokalizacji defektu, starając się zdobyć szczegółowe informacje o stanie technicznym poszczególnych modułów 
analysing much greater number of diagnostic parameters is required, whose values, when approaching the limits of the operation field of tolerance, would signal slight changes of the technical condition, which are characteristic of the ,imminent" unserviceable state. Therefore it can be concluded that the exactness of the determination of the diagnostic tolerances determines thoroughness and quality of a diagnosis [1].

\section{A tolerance field of a diagnostic parameter}

The problem of selection of a set of appropriate diagnostic parameters and of their operating tolerances is particularly complex while analysing the engine dynamic properties and its working spaces in particular. This issue is additionally complicated with the fact that the engine, which discharges an exhaust gas and sucks air in cycles (pulses), cooperates with the turbocharger which is viewed as the fluid-flow machine of continuous flow. One of the very effective means, possible to be used in searching for an analytical solution of the problem, is the application of the notion of the distance between functions, known from the classic mathematical analysis. The distance between two continuous functions $\mathrm{X}(\tau)$ and $\mathrm{X}^{\prime}(\tau)$ can be determined from the following formula:

$$
J=\sqrt{\int_{\tau=0}^{\tau=t}\left[X(\tau)-X^{\prime}(\tau)\right]^{2} d \tau}
$$

If the forms of the compared functions are unknown, but a set of discrete values of recorded dynamic processes is available, the functional $\mathrm{J}\left(\mathrm{x}, \mathrm{x}^{\prime}\right)$, called the metric, can be determined, the value of which, calculated for the selected pair of elements $\left\{\mathrm{x}, \mathrm{x}^{\prime}\right\}$ of the compared process courses, stands for distance between the points $x$ and $x$ '. The so defined metric can be used in two ways:

- for quantitative assessment of the comparable courses-by calculating its average value:

$$
J\left(x, x^{\prime}\right)=\sqrt{\sum_{\tau=1}^{t}\left(x_{\tau}-x_{\tau}^{\prime}\right)^{2}}
$$

- for qualitative assessment of the comparable courses - by calculating its maximum value:

$$
\mathrm{J}_{\max }\left(\mathrm{x}, \mathrm{x}^{\prime}\right)=\max _{0 \leq \tau \leq \mathrm{t}}\left|\mathrm{x}_{\mathrm{t}}-\mathrm{x}_{\tau}^{\prime}\right|
$$

In both cases the number, which expresses the definite distance between the compared sets stands for the metric value. A geometric meaning of the distance is highlighted in Fig. 1.

The notion of the reference metric whose dimensionless value can serve as an universal comparative index for all the analysed courses and is introduced in order to enable a comparative analysis of a great number of the dynamic courses

$$
\delta J=\sqrt{\sum_{\tau=0}^{t}\left(\frac{x_{\tau}-x_{\tau}^{\prime}}{x_{\tau}}\right)^{2}} \cdot 100 \%
$$

funkcjonalnych. Niezbędna jest zatem analiza znacznie większej liczby parametrów diagnostycznych, których wartości, zbliżając się do granic eksploatacyjnego pola tolerancji, sygnalizowałyby symptomy nieznacznych zmian stanu technicznego charakterystyczne dla ,zbliżającego się" stanu niezdatności. Wynika stąd wniosek, że precyzyjne wyznaczenie tolerancji diagnostycznych determinuje jakość stawianej diagnozy [1].

\section{Pole tolerancji parametru diagnostycznego}

Problem wytypowania zbioru adekwatnych parametrów diagnostycznych oraz granic ich tolerancji eksploatacyjnych jest szczególnie złożony w procesie analizy właściwości dynamicznych silnika, a zwłaszcza jego przestrzeni roboczych. Sytuacje komplikuje dodatkowo współpraca silnika wydalającego spaliny i pobierającego powietrze w sposób cykliczny (pulsacyjny) z turbosprężarką, będącą maszyną przepływową o przepływie ciągłym. Jednym z efektywniejszych narzędzi możliwych do zastosowania na drodze analitycznego rozwiązania zagadnienia jest znane w klasycznej analizie matematycznej pojecie odległości pomiędzy funkcjami. Odległość pomiędzy dwoma ciągłymi funkcjami $X(\tau)$ i $X^{\prime}(\tau)$ można określić wg wzoru (1).

Jeżeli nie są znane postacie porównywanych funkcji, a dysponujemy jedynie zbiorem dyskretnych wartości zarejestrowanych przebiegów dynamicznych, to można wyznaczyć funkcjonał J(x, x'), nazywany metryką, którego wartość dla ustalonej pary elementów $\left\{\mathrm{x}, \mathrm{x}^{\prime}\right\}$ porównywanych przebiegów stanowi odległość pomiędzy punktami x i x'. Geometryczny sens odległości wyjaśnia rys. 1. Tak zdefiniowaną metrykę można wykorzystywać w dwojaki sposób:

- do oceny ilościowej porównywanych przebiegów - jako wartość uśrednioną (2) oraz

- do oceny jakościowej porównywanych przebiegów - jako wartość maksymalną (3).

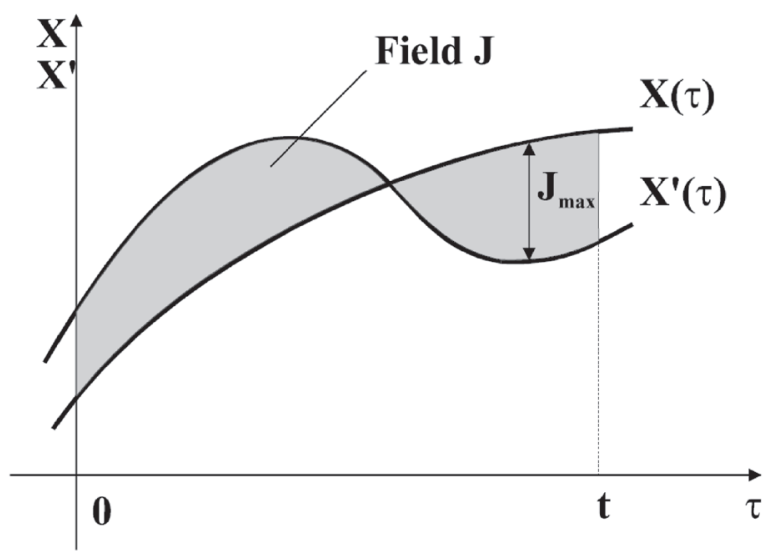

Fig. 1. Geometric interpretation of the distance between two functions recorded in the form of different sets of the function discrete values:

Rys. 1. Interpretacja geometryczna odległości pomiędzy funkcjami

W obu przypadkach wartością metryki będzie liczba wyrażająca konkretny wymiar odległości porównywanych zbiorów. W celu przeprowadzenia analizy porównawczej 
The metric value defined by (4) is the value of the diagnostic parameter which quantitatively characterises a given unserviceable state, if $X_{\tau}$ is a discrete value set of control parameter course changes during engine operation of a considered defect-free engine system (standard one) and $\mathrm{X}^{\text {' }}$ is a course of changes of the same parameter for the system with a defect. The metric value is used as a diagnostic sensitivity measure of the parameter.

The values of the diagnostic parameters $\delta x_{j}$ shown in percentage in the table, were determined by comparing the standard time courses of the gas-dynamic parameters, recorded during a simulation of the engine operation being in full operative state, with the relevant time courses of the engine containing the modelled unserviceable states $\mathrm{S}_{\mathrm{n} 1}, \mathrm{~S}_{\mathrm{n} 2}$, $\mathrm{S}_{\mathrm{n} 3}, \mathrm{~S}_{\mathrm{n} 4}, \mathrm{~S}_{\mathrm{n} 5}, \mathrm{~S}_{\mathrm{n} 6}, \mathrm{~S}_{\mathrm{n} 7}, \mathrm{~S}_{\mathrm{n} 8}, \mathrm{~S}_{\mathrm{n} 9}, \mathrm{~S}_{\mathrm{n} 10}, \mathrm{~S}_{\mathrm{n} 11}, \mathrm{~S}_{\mathrm{n} 12}, \mathrm{~S}_{\mathrm{n} 13}, \mathrm{~S}_{\mathrm{n} 14}$.

The engine unserviceable operational states as well as the state of its full operativeness used in the analysis have been acquired in the result of mathematical modelling of the gas dynamic processes worked out in the marine diesel engine working spaces. The analysed time courses of gas-dynamic parameters (temperatures T, pressures $p$ and the displacement velocity of the peak amplitude of the exhaust pressure wave $v$ ) have been evaluated for the selected control sections of the exhaust discharge channel (the channel connecting the engine cylinders with the turbine of the turbocharging unit). The obtained results are shown in Tab. 1. większej liczby zarejestrowanych przebiegów dynamicznych, w różnych zbiorach (jednostkach) dyskretnych wartości funkcji, wprowadza się pojęcie metryki odniesieniowej, której bezwymiarowa wartość może stanowić uniwersalny wskaźnik porównawczy dla wszystkich analizowanych przebiegów (4).

Jeżeli $X_{\tau}$ będzie stanowić zbiór dyskretnych wartości przebiegu zmian parametru kontrolnego analizowanego silnika bez defektów (wzorcowego), zaś zbiór $\mathrm{X}_{\tau}^{\prime}$ - przebieg zmian tego samego parametru dla układu z defektem, to zdefiniowana zależnością (4) wartość metryki będzie wartością parametru diagnostycznego, charakteryzującego określony stan niezdatności pod względem ilościowym. Będzie ona stanowić miarę czułości diagnostycznej parametru. Procentowe wartości metryk (parametrów diagnostycznych) wyznaczono metodą porównania wzorcowych przebiegów czasowych parametrów termogazodynamicznych, zarejestrowanych w wyniku symulacji pracy silnika w stanie pełnej zdatności eksploatacyjnej, z odpowiednimi przebiegami czasowymi - dla silnika z zamodelowanymi stanami niezdatności $\mathrm{S}_{\mathrm{n} 1}, \mathrm{~S}_{\mathrm{n} 2}, \mathrm{~S}_{\mathrm{n} 3}, \mathrm{~S}_{\mathrm{n} 4}, \mathrm{~S}_{\mathrm{n} 5}, \mathrm{~S}_{\mathrm{n} 6}, \mathrm{~S}_{\mathrm{n} 7}, \mathrm{~S}_{\mathrm{n} 8}$, $\mathrm{S}_{\mathrm{n} 9}, \mathrm{~S}_{\mathrm{n} 10}, \mathrm{~S}_{\mathrm{n} 11}, \mathrm{~S}_{\mathrm{n} 12}, \mathrm{~S}_{\mathrm{n} 13}$ i $\mathrm{S}_{\mathrm{n} 14}$. Wykorzystywane $\mathrm{W}$ analizie stany niezdatności eksploatacyjnej silnika oraz stan pełnej zdatności technicznej uzyskano w wyniku modelowania matematycznego procesów gazodynamicznych zachodzących w przestrzeniach roboczych silnika okrętowe-
Table 1. The metric values $\delta \mathrm{x}_{\mathrm{j}}$ for the modelled operational unserviceable states of the working spaces of SULZER engine 6AL20/24 type

Tabela 1. Zbiór wartości metryk dla modelowanych stanów niezdatności przestrzeni roboczych silnika SULZER typu 6AL20/24

\begin{tabular}{|c|c|c|c|c|c|c|c|c|c|}
\hline & \multicolumn{8}{|c|}{ Operational unserviceable states/stan niezdatności eksploatacyjnej } \\
\hline & & $\mathrm{S}_{\mathrm{n} 1}$ & $\mathrm{~S}_{\mathrm{n} 2}$ & $\mathrm{~S}_{\mathrm{n} 3}$ & $\mathrm{~S}_{\mathrm{n} 4}$ & $\mathrm{~S}_{\mathrm{n} 5}$ & $\mathrm{~S}_{\mathrm{n} 6}$ & $\mathrm{~S}_{\mathrm{n} 7}$ & $\mathrm{~S}_{\mathrm{n} 8}$ \\
\hline & & {$[\%]$} & {$[\%]$} & {$[\%]$} & {$[\%]$} & {$[\%]$} & {$[\%]$} & {$[\%]$} & {$[\%]$} \\
\hline \multirow{9}{*}{ 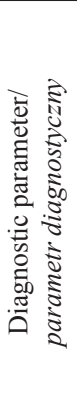 } & $\delta \mathrm{T}$ & 6,28 & 12,7 & 15,7 & 6,1 & 12,4 & 15,4 & 20,5 & 20,5 \\
\hline & $\delta \mathrm{p}$ & 6,81 & 13,9 & 17,2 & 6,35 & 13 & 16,1 & 20,7 & 20,7 \\
\hline & $\delta \mathrm{v}$ & 20,3 & 50,6 & 49,8 & 15,2 & 30,4 & 37,4 & 31,9 & 31,9 \\
\hline & & \multicolumn{7}{|c|}{ Operational unserviceable states/stan niezdatności eksploatacyjnej } & \\
\hline & & $\mathrm{S}_{\mathrm{n} 9}$ & $\mathrm{~S}_{\mathrm{n} 10}$ & $\mathrm{~S}_{\mathrm{n} 11}$ & $\mathrm{~S}_{\mathrm{n} 12}$ & $\mathrm{~S}_{\mathrm{n} 13}$ & $\mathrm{~S}_{\mathrm{n} 14}$ & $\mathrm{~S}_{\mathrm{n} 15}$ & \\
\hline & & [\%] & {$[\%]$} & {$[\%]$} & [\%] & {$[\%]$} & [\%] & {$[\%]$} & \\
\hline & $\delta \mathrm{T}$ & 13,5 & 14 & 6,96 & 9,57 & 5,31 & 7,75 & 0 & \\
\hline & $\delta \mathrm{p}$ & 13,9 & 14,5 & 6,96 & 10 & 5,6 & 8,22 & 0 & \\
\hline & $\delta \mathrm{v}$ & 22 & 25 & 14,4 & 20 & 10,8 & 15,3 & 0 & \\
\hline
\end{tabular}

go. Analizowane przebiegi czasowe parametrów gazodynamicznych (temperatury T, ciśnienia p i prędkości przemieszczanie się szczytowej amplitudy ciśnienia spalin v) określano dla wytypowanego przekroju kontrolnego kanału wylotu spalin (kanału łączącego cylindry silnika z turbiną zespołu turbosprężarki). Uzyskane wyniki przedstawiono w tab. 1, gdzie: where:

$\mathrm{S}_{\mathrm{n} 1}$ - reduction of the active cross-sections of the outlet valves of cylinder 1,2 and 3 by $5 \%$,

$\mathrm{S}_{\mathrm{n} 2}$ - reduction of the active cross-sections of the outlet valves of cylinder 1, 2 and 3 by $20 \%$,

$\mathrm{S}_{\mathrm{n} 3}$ - reduction of the active cross-sections of the outlet valves of cylinder 1, 2 and 3 by $30 \%$,

$\mathrm{S}_{\mathrm{n} 4}$ - reduction of the active cross-sections of the outlet valves of cylinder 1 by $5 \%$,

$\mathrm{S}_{\mathrm{n} 5}$ - reduction of the active cross-sections of the outlet valves of cylinder 1 by $20 \%$,
$\mathrm{S}_{\mathrm{n} 1}$ - zmniejszenie czynnych pól przekrojów zaworów wylotowych cylindrów nr 1,2 i 3 o $5 \%$,

$\mathrm{S}_{\mathrm{n} 2}-$ zmniejszenie czynnych pól przekrojów zaworów wylotowych cylindrów nr 1, 2 i 3 o $20 \%$,

$\mathrm{S}_{\mathrm{n} 3}$ - zmniejszenie czynnych pól przekrojów zaworów wylotowych cylindrów $\mathrm{nr} 1,2$ i 3 o $30 \%$,

$\mathrm{S}_{\mathrm{n} 4}$ - zmniejszenie czynnych pól przekrojów zaworów wylotowych cylindra nr 1 o $5 \%$,

$\mathrm{S}_{\mathrm{n} 5}$ - zmniejszenie czynnych pól przekrojów zaworów wylotowych cylindra $\mathrm{nr} 1$ o $20 \%$, 
$\mathrm{S}_{\mathrm{n} 6}$ - reduction of the active cross-sections of the outlet valves of cylinder 1 by $30 \%$,

$\mathrm{S}_{\mathrm{n} 7}$ - change of the opening and closing angles of the outlet valves of cylinder 1,2 and 3 by $+5^{\circ}$ crankshaft revolution (CA), $\mathrm{S}_{\mathrm{n} 8}$ - change of the opening and closing angles of the outlet valves of cylinder 1,2 and 3 by $-5^{\circ}$ crankshaft revolution (CA), $\mathrm{S}_{\mathrm{n} 9}$ - change of the opening and closing angles of the outlet valves of cylinder 1 by $+5^{\circ}$ crankshaft revolution (CA), $\mathrm{S}_{\mathrm{n} 10}$ - change of the opening and closing angles of the outlet valves of cylinder 1 by $-5^{\circ}$ crankshaft revolution (CA),

$\mathrm{S}_{\mathrm{n} 11}$ - reduction of the combustion chamber volumes of cylinder section nr 1,2 and 3 by $25 \%$,

$\mathrm{S}_{\mathrm{n} 12}$ - reduction of the combustion chamber volumes of cylinder section $\mathrm{nr} 1,2$ and 3 by $50 \%$,

$\mathrm{S}_{\mathrm{n} 13}$ - reduction of the combustion chamber volume of cylinder section $\mathrm{nr} 1$ by $25 \%$,

$\mathrm{S}_{\mathrm{n} 14}$ - reduction of the combustion chamber volume of cylinder section $\mathrm{nr} 1$ by $50 \%$,

$\mathrm{S}_{\mathrm{n} 15}$ - state of full operativeness of the engine working spaces.

\section{Quantity of diagnostic information}

The technical state of each module of the marine diesel engine may be described even by a large set of diagnostic parameters (directly measurable and computational ones), preliminarily determined by analysing its functional scheme. It is not reasonable to perform the analysis of all possible parameters during diagnostic investigations and it should be reduced to searching for an optimum set of these parameters by the use of which it is possible to control the state and locate the identifiable (known an typical) defects of the engine. Therefore, it is necessary to minimise the elaborated set of hypothetical diagnostic parameters in compliance with the following criteria:

- criterion of the maximum quantity of gained information about unserviceable states

- criterion of diagnostic dependability of an investigated type of engine.

Such a situation should aim at a state when a finally verified set of parameters would enable the identification of each operational unserviceable state of an analysed structural component. An ideal situation would be if a single diagnostic parameter unequivocally characterised a given defect. However, in the case of marine engines, as it results from the performed investigations, several possible unserviceable states can be related to a single diagnostic parameter $[3,4]$.

An uncertainty level analysis of the determined set of unserviceable states is usually performed in order to rationally select the diagnostic parameters. The quantity of diagnostic information on the engine technical condition contained in each of the analysed parameters can be determined (according to Shannon) by means of [2]:

- unconditional entropy - being an uncertainty measure of a set of unserviceable states:

$$
E\left(S_{n}\right)=-\sum_{i=0}^{k} p_{b i} \cdot \log _{2} p_{b i}
$$

$\mathrm{S}_{\mathrm{n} 6}$ - zmniejszenie czynnych pól przekrojów zaworów wylotowych cylindra nr 1 o $30 \%$,

$\mathrm{S}_{\mathrm{n} 7}$ - zmiana kąta otwarcia i zamknięcia zaworów wylotowych cylindrów $\mathrm{nr} 1,2$ i 3 o $+5^{\circ} \mathrm{OWK}$,

$\mathrm{S}_{\mathrm{n} 8}$ - zmiana kąta otwarcia i zamknięcia zaworów wylotowych cylindrów nr 1, 2 i 3 o $-5^{\circ} \mathrm{OWK}$,

$\mathrm{S}_{\mathrm{n} 9}$ - zmiana kąta otwarcia i zamknięcia zaworów wylotowych cylindra $\mathrm{nr} 1 \mathrm{o}+5^{\circ} \mathrm{OWK}$,

$\mathrm{S}_{\mathrm{n} 10}$ - zmiana kąta otwarcia i zamknięcia zaworów wylotowych cylindra $\mathrm{nr} 1 \mathrm{o}-5^{\circ} \mathrm{OWK}$,

$\mathrm{S}_{\mathrm{n} 11}$ - zmniejszenie objętości komory spalania sekcji cylindrowych nr 1, 2 i 3 o $25 \%$,

$\mathrm{S}_{\mathrm{n} 12}$ - zmniejszenie objętości komory spalania sekcji cylindrowych nr 1, 2 i 3 o $50 \%$,

$\mathrm{S}_{\mathrm{n} 13}$ - zmniejszenie objętości komory spalania sekcji cylindrowej $n r 1$ o $25 \%$,

$\mathrm{S}_{\mathrm{n} 14}$ - zmniejszenie objętości komory spalania sekcji cylindrowej nr 1 o $50 \%$,

$\mathrm{S}_{\mathrm{n} 15}$ - stan pełnej zdatności eksploatacyjnej przestrzeni roboczych silnika.

\section{Ilość informacji diagnostycznej}

Stan techniczny każdego modułu silnika okrętowego może opisywać nawet dość liczny zbiór parametrów diagnostycznych (bezpośrednio mierzalnych i obliczeniowych), wyznaczonych wstępnie metodą analizy jego schematu funkcjonalnego. W procesie badań diagnostycznych niecelowe jest śledzenie trendu zmian wartości wszystkich możliwych parametrów. Niezbędną analizę należy ograniczyć do minimalnego ich zbioru zapewniającego kontrolę stanu oraz lokalizację identyfikowalnych (znanych i typowych) defektów silnika. Należy zatem przeprowadzić minimalizację opracowanego hipotetycznie zbioru parametrów diagnostycznych według następujących kryteriów:

- maksimum ilości wnoszonej informacji diagnostycznej o stanach niezdatności

- podatności kontrolnej badanego typu silnika.

Powinno się dążyć do sytuacji, w której ostatecznie zweryfikowany zbiór parametrów zapewni identyfikację każdego ze stanów niezdatności eksploatacyjnej analizowanego zespołu konstrukcyjnego. Idealna sytuacja miałaby miejsce wtedy, gdyby jeden parametr diagnostyczny charakteryzował jednoznacznie określone uszkodzenie [3, 4]. Jak wynika z przeprowadzonych badań, w przypadku silników okrętowych jednemu parametrowi diagnostycznemu odpowiada kilka możliwych stanów niezdatności eksploatacyjnej.

W celu racjonalnego przeprowadzenia selekcji parametrów diagnostycznych dokonuje się analizy stopnia nieokreśloności wyznaczonego zbioru stanów niezdatności. Ilość informacji diagnostycznej o stanie technicznym silnika, zawartą w każdym $\mathrm{z}$ analizowanych parametrów, można wyznaczyć za pomocą [2]:

- entropii bezwarunkowej - jako miary nieokreśloności zbioru stanów niezdatności (5), gdzie: $\mathrm{S}_{\mathrm{n}}$ - skończony zbiór stanów niezdatności, $\mathrm{k}$ - liczba prawdopodobnych stanów niezdatności tworzących zbiór $\mathrm{S}_{\mathrm{n}}, \mathrm{p}_{\mathrm{bi}}-$ 
where: $\mathrm{S}_{\mathrm{n}}$ - finite set of engine unserviceable states, $\mathrm{k}$ - number of possible unserviceable states forming the set $\mathrm{S}_{\mathrm{n}}, \mathrm{p}_{\mathrm{bi}}$ - occurrence probability of one of possible unserviceable states;

- average conditional entropy - which makes it possible to calculate an uncertainty drop of a set of unserviceable states provided that $\delta x_{j}$ value of one (consecutive) diagnostic parameter is determined:

$$
E\left(\frac{S_{n}}{\delta x_{i}}\right)=p_{b j}\left(\delta x_{j}\right) E_{\delta x j} \cdot\left(S_{n}\right)+p_{b j}\left(\overline{\delta x_{j}}\right) \cdot E_{\overline{\delta x j}}\left(S_{n}\right)
$$

where: $\delta x_{j}-$ diagnostic parameter value, $\overline{\delta x}_{\mathrm{j}}-$ value opposite to $\delta x_{j}\left(\overline{\delta x_{j}}=1-\delta x\right)_{j}, p_{b j}\left(\delta x_{j}\right), p_{b j}\left(\overline{\delta x_{j}}\right)$ - probability of reaction of the parameter $\delta x_{j}$ to engine unserviceable states, and that of no $\overline{\delta x}_{\mathrm{j}}$ reaction of these states, respectively, $\mathrm{E}_{\delta \mathrm{x}_{j}}\left(\mathrm{~S}_{\mathrm{n}}\right), \mathrm{E}_{\overline{\delta \mathrm{x}_{j}}}\left(\mathrm{~S}_{\mathrm{n}}\right)$ - conditional entropy values of the set of unserviceable states after determination of $\delta x_{j}$ diagnostic parameter value, respectively for the sub-set of the states to which the parameter $\delta x_{j}$ reacts and the sub-set of the states to which the parameter $\overline{\delta x}_{j}$ does not react.

The quantity of diagnostic information on $\mathrm{S}_{\mathrm{ni}}$ unserviceable states of the engine working spaces, which is contained in $\delta x_{j}$, can be obtained using the following expression [2]:

$$
I_{\delta x j \longrightarrow S n}=E\left(S_{n}\right)-E\left(\frac{S_{n}}{\delta x_{j}}\right)
$$

Mutual relationships between the finite set of the unserviceable states $\mathrm{S}_{\mathrm{ni}}$ of the engine working spaces and the diagnostic parameters $\delta x_{j}$ identifying these states can be clearly presented by means of "diagnostic matrices" shown in Tab. 2. It was assumed that „1" has to be put into the cell at the $\mathrm{j}$-th matrix row and $\mathrm{i}$-th column crossing, if the $\delta \mathrm{x}$ diagnostic parameter reacts to the unserviceable state $\mathrm{S}_{\mathrm{ni}}$ by $10 \%$ excess of the tolerance field limits $\left(\delta x_{j}>10 \%\right)$. If a parameter does not react to the unserviceable state, , 0 " has to be put in. In the last column of the matrix the quantity of diagnostic information obtained from (7) has to be put in.

How it results from numerical data gathered in the diagnostic matrix (Tab. 2), by applying the criterion of maximum quantity of diagnostic information $\mathrm{I}=\max$, exhaust temperature can be chosen as the best diagnostic parameter $\left(\mathrm{I}_{\delta \mathrm{T}}=1.0\right)$. This parameter makes it possible to limit diagnostic inference process to eight states on which the parameter reacts or to seven remaining states, in dependence of the value reached in the supervisory process.

The exhaust pressure in a discharge channel could be also an equally useful diagnostic parameter, where prawdopodobieństwo pojawienia się jednego z możliwych stanów niezdatności,

- uśrednionej entropii warunkowej - pozwalającej obliczyć, o ile zmaleje nieokreśloność zbioru stanów niezdatności, pod warunkiem wyznaczenia jednego (kolejnego) parametru diagnostycznego $\delta x_{i}(6)$, gdzie: $\delta x_{j}$ - wartość parametru diagnostycznego, $\overline{\delta x}_{j}-$ wartość przeciwna do $\delta x_{j}\left(\overline{\delta x_{j}}=1-\delta x\right)_{j}, \quad p_{b j}\left(\delta x_{j}\right), p_{b j}\left(\overline{\delta x_{j}}\right)$ prawdopodobieństwo, $\mathrm{z}$ jakim reaguje parametr $\delta \mathrm{x}_{\mathrm{j}}$ na stany niezdatności silnika oraz prawdopodobieństwo, na które $\overline{\delta x}_{j}$ nie reaguje, $E_{\delta x_{j}}\left(S_{n}\right), E_{\overline{\delta x}}\left(S_{n}\right)$ - warunkowe entropie zbioru niezdatności po określeniu $\delta \mathrm{x}_{\mathrm{j}}$ parametru diagnostycznego, odpowiednio dla podzbioru stanów, na które reaguje parametr $\delta x_{j}$ oraz podzbioru stanów, na które $\overline{\delta x}_{\mathrm{j}}$ nie reaguje.

Ilość informacji diagnostycznej, którą zawiera parametr $\delta x_{j}$ o stanach niezdatności w układzie przestrzeni roboczych silnika okrętowego $\mathrm{S}_{\mathrm{n}}$ można wyznaczyć za pomocą wyrażenia (7) [2].

Wzajemne powiązania pomiędzy skończonym zbiorem stanów niezdatności przestrzeni roboczych silnika $\mathrm{S}_{\mathrm{ni}}$ i parametrami diagnostycznymi $\delta x_{\text {j, }}$, identyfikującymi te stany, można przejrzyście przedstawić za pomocą tzw. macierzy diagnostycznych (tab. 2). Przyjęto, że jeżeli parametr diagnostyczny $\delta x_{j}$ reaguje na stan niezdatności $S_{n i}$ dziesięcioprocentowym przekroczeniem granic pola tolerancji $\left(\delta x_{j} \geq 10 \%\right)$, to $w$ polu macierzy diagnostycznej, na przecięciu j-tego wiersza z i-tą kolumną wstawia się „,1”. Jeżeli parametr nie reaguje na stan niezdatności - wstawia się, ,0".

Jak wynika $\mathrm{z}$ danych liczbowych macierzy diagnostycznej (tab. 2), stosując kryterium maksymalnej ilości informacji diagnostycznej I = max, można wybrać temperaturę spalin wylotowych jako najlepszy parametr diagnostyczny $\left(\mathrm{I}_{\delta \mathrm{T}}=1,0\right)$. Umożliwia on ograniczenie wnioskowania diagnostycznego do ośmiu stanów, na które reaguje, lub do siedmiu pozostałych stanów, w zależności od wartości jaką osiągnie $\mathrm{w}$ procesie kontrolnym.

Równie przydatnym parametrem diagnostycznym jest ciśnienie spalin w kanale wylotowym, gdzie ilość wnoszonej informacji diagnostycznej o rozpatrywanych stanach technicznych przestrzeni roboczych silnika wynosi $\mathrm{I}_{\delta \mathrm{p}}=0,970$.

Table 2. Diagnostic matrix of the SULZER engine working spaces 6AL20/24 type

\begin{tabular}{|c|c|c|c|c|c|c|c|c|c|}
\hline & \multicolumn{8}{|c|}{ Operational unserviceable states/stan niezdatności eksploatacyjnej } \\
\hline & & $\mathrm{S}_{\mathrm{n} 1}$ & $\mathrm{~S}_{\mathrm{n} 2}$ & $\mathrm{~S}_{\mathrm{n} 3}$ & $\mathrm{~S}_{\mathrm{n} 4}$ & $\mathrm{~S}_{\mathrm{n} 5}$ & $\mathrm{~S}_{\mathrm{n} 6}$ & $\mathrm{~S}_{\mathrm{n} 7}$ & $\mathrm{~S}_{\mathrm{n} 8}$ \\
\hline \multirow{8}{*}{ 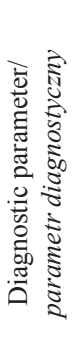 } & $\delta \mathrm{T}$ & 0 & 1 & 1 & 0 & 1 & 1 & 1 & 1 \\
\hline & $\delta p$ & 0 & 1 & 1 & 0 & 1 & 1 & 1 & 1 \\
\hline & $\delta \mathrm{v}$ & 1 & 1 & 1 & 1 & 1 & 1 & 1 & 1 \\
\hline & & \multicolumn{8}{|c|}{ Operational unserviceable states/stan niezdatności eksploatacyjnej } \\
\hline & & $\mathrm{S}_{\mathrm{n} 9}$ & $\mathrm{~S}_{\mathrm{n} 10}$ & $S_{n 11}$ & $\mathrm{~S}_{\mathrm{n} 12}$ & $\mathrm{~S}_{\mathrm{n} 13}$ & $\mathrm{~S}_{\mathrm{n} 14}$ & $\mathrm{~S}_{\mathrm{n} 15}$ & $\mathrm{I}$ \\
\hline & $\delta \mathrm{T}$ & 1 & 1 & 0 & 0 & 0 & 0 & 0 & 1.000 \\
\hline & $\delta \mathrm{p}$ & 11 & 1 & 0 & 1 & 0 & 0 & 0 & 0.970 \\
\hline & $\delta \mathrm{v}$ & 11 & 1 & 1 & 1 & 1 & 1 & 0 & 0.355 \\
\hline
\end{tabular}
Tabela 2. Macierze diagnostyczne przestrzeni roboczych silnika SULZER typu 6AL20/24 
the quantity of gained diagnostic information about considered technical states of the engine working spaces equals $\mathrm{I}_{\delta \mathrm{p}}=0.970$.

The velocity of the exhaust flow, however, should be definitely rejected because this parameter brings the smallest quantity of information $\mathrm{I}_{\delta \mathrm{v}}=0.355$. It reacts to all the considered unserviceable states by exceeding the settled borders of operational tolerances.

In order to select adequate diagnostic parameters a criterion of supervisory susceptibility should also be applied as well as the possibility to realize the measurement. Because the measurements of the working medium temperature are characterized with a considerable inertia forcing the application thermocouples at the diameter of about ten micrometers [5] the exhaust pressure in the discharge channel should be chosen for further estimation because its measurement seems to be the most rational with regard to diagnosing technology of marine diesel engines.

It has been assumed that ,k" unserviceable states of the engine working spaces, $S_{n i}$, where $i=1,2, \ldots, k$, create a finite set of equally probable events $p_{b i}=1 / k$. This .is practically confirmed with the results of the diagnostic tests performed out in the aviation and automotive industries as well as our own diagnostic investigations carried out on marine engines operated in the Polish Navy [2, 3, 4]. Hence, the expression defining the unconditional entropy has got the following formula:

$$
E\left(S_{n}\right)=-\sum_{i=1}^{k} \log _{2} \frac{1}{k}=\log _{2} k
$$

As $\mathrm{k}=15$ for the considered system, the unconditional entropy is:

$$
E\left(S_{n}\right)=\log _{2} 15=3.908
$$

The selected diagnostic parameters $\delta \mathrm{T}, \delta \mathrm{p}$ and $\delta \mathrm{v}$ presented in matrix 2, contain only a part of diagnostic information about the technical condition of the engine working spaces. In spite of the unfulfilled condition which determines the preliminary uncertainty measure of the considered states:

$$
E\left(S_{n}\right)=I(\delta T)+I(\delta p)+I(\delta v)
$$

it is possible to distinguish four groups of equally probable unserviceable states. For instance, by analysing the set of diagnostic parameters (Tab. 2) it could be concluded that if the result $\{\delta \mathrm{T}, \delta \mathrm{p}, \delta \mathrm{v}\}=\{0,0,1\}$ appears during the diagnostic investigation it means that unserviceable states, respectively: $\mathrm{S}_{\mathrm{n} 1}, \mathrm{~S}_{\mathrm{n} 4}, \mathrm{~S}_{\mathrm{n} 11}, \mathrm{~S}_{\mathrm{n} 13}$ and $\mathrm{S}_{\mathrm{n} 14}$ could occur. No identical result appears except for those five cases.

Moreover, equally probable unserviceable states $\mathrm{S}_{\mathrm{n} 2}, \mathrm{~S}_{\mathrm{n} 3}$,

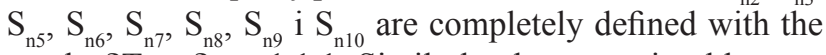
result: $\delta \mathrm{T}, \mathrm{vp}, \delta \mathrm{v}=1,1,1$. Similarly, the unserviceable state $\mathrm{S}_{\mathrm{n} 12}$ is defined $-\delta \mathrm{T}, \delta \mathrm{p}, \delta \mathrm{v}=0,0,1$. The obtained result of $\{\delta \mathrm{T}, \delta \mathrm{p}, \delta \mathrm{v}\}=\{0,0,0\}$ might indicate that the engine working spaces are in full operativeness, on condition that the
Natomiast z całą pewnością można odrzucić prędkość przepływu spalin, która wnosi najmniejszą ilość informacji $\mathrm{I}_{\delta \mathrm{v}}=0,355$. Parametr ten reaguje na wszystkie rozpatrywane stany niezdatności przekroczeniem ustalonych granic tolerancji eksploatacyjnych.

W takim przypadku do selekcji adekwatnych parametrów diagnostycznych należy zastosować kryterium podatności kontrolnej badanego typu silnika oraz możliwość realizacji pomiaru. Ponieważ pomiary temperatury czynnika roboczego charakteryzują się znaczną inercyjnością, co wymusza konieczność zastosowania termoelementów o średnicy rzędu kilkudziesięciu mikrometrów [5], do dalszej oceny należy wytypować ciśnienie spalin w kanale, którego pomiar ze względu na technologię diagnozowania silników okrętowych wydaje się najbardziej racjonalny.

Na podstawie wyników badan diagnostycznych silników spalinowych eksploatowanych w motoryzacji i lotnictwie $[2,3,4]$ oraz wyników badań własnych przeprowadzonych na silnikach okrętowych Marynarki Wojennej RP przyjęto, że „k” stanów niezdatności przestrzeni roboczych silnika $\mathrm{S}_{\text {ni }}$, gdzie $\mathrm{i}=1, \ldots, \mathrm{k}$, tworzy skończony zbiór jednakowo prawdopodobnych zdarzeń $\mathrm{p}_{\mathrm{bi}}=1 / \mathrm{k}$. Zatem wyrażenie definiujące entropię bezwarunkową przyjmuje postać (8).

Dla analizowanego układu $\mathrm{k}=15$, stąd entropia bezwarunkowa wynosi (9).

Wybrane parametry diagnostyczne $\delta \mathrm{T}, \delta$ p oraz $\delta \mathrm{v}$, zestawione w matrycy diagnostycznej 2 , zawierają tylko część informacji diagnostycznej o stanie technicznym przestrzeni roboczych silnika. Mimo iż nie jest spełniony warunek jednoznacznie określający początkową miarę nieokreśloności rozpatrywanych stanów, $\mathrm{E}\left(\mathrm{S}_{\mathrm{n}}\right)$ wynosi $(10)$.

Możliwe jest rozróżnienie czterech grup równie prawdopodobnych stanów niezdatności. Przykładowo, analizując zbiór parametrów diagnostycznych (macierz 2), można wnioskować, że jeżeli w procesie badania diagnostycznego pojawi się rezultat: $\delta \mathrm{T}, \delta \mathrm{p}, \delta \mathrm{v}=0,0,1$, to świadczyć to może o wystąpieniu stanów niezdatności, odpowiednio: $\mathrm{S}_{\mathrm{n} 1}, \mathrm{~S}_{\mathrm{n} 4}, \mathrm{~S}_{\mathrm{n} 11}, \mathrm{~S}_{\mathrm{n} 13}$ i $\mathrm{S}_{\mathrm{n} 14}$. Identyczny układ rezultatu badań nie występuje nigdzie poza tymi pięcioma przypadkami.

Jednocześnie równie prawdopodobne wystąpienie stanów niezdatności $\mathrm{S}_{\mathrm{n} 2}, \mathrm{~S}_{\mathrm{n} 3}, \mathrm{~S}_{\mathrm{n} 5}, \mathrm{~S}_{\mathrm{n} 6}, \mathrm{~S}_{\mathrm{n} 7}, \mathrm{~S}_{\mathrm{n} 8}, \mathrm{~S}_{\mathrm{n} 9}$ i $\mathrm{S}_{\mathrm{n} 10}$ wyczerpująco definiuje rezultat: $\delta \mathrm{T}, \delta \mathrm{p}, \delta \mathrm{v}=1,1,1$. Podobnie zidentyfikować można stan niezdatności $\mathrm{Sn}_{12}-\delta \mathrm{T}, \delta \mathrm{p}, \delta \mathrm{v}$ $=0,0,1$. Uzyskanie $\mathrm{w}$ procesie badania diagnostycznego rezultatu $\delta \mathrm{T}, \delta \mathrm{p}, \delta \mathrm{v}=0,0,0$ mogłoby sygnalizować pełną zdatność przestrzeni roboczych silnika do użytkowania pod warunkiem spełnienia zależności (10). Jednak tak nie jest, gdyż suma ilości informacji diagnostycznej o stanie technicznym przestrzeni roboczych silnika wnoszonej przez parametry $\mathrm{T}, \mathrm{p}, \mathrm{v}$ wynosi 2,325 , a entropia bezwarunkowa jest równa 3,908. Dla zniwelowania stopnia nieokreśloności rozpatrywanych stanów niezdatności (brakujące 1,583 ilości informacji diagnostycznej) należy uzupełnić zbiór parametrów diagnostycznych, tak aby spełniony był warunek jednoznacznej rozróżnialności tych stanów. 
expression (10) is fulfilled. But it is not like it seems to be, because the sum of the quantity of diagnostic information about unserviceable states, contributed with the parameters $\mathrm{T}, \mathrm{p}, \mathrm{v}$, equals 2.325 and the unconditional entropy equals 3.908. In order to level a degree of the uncertainty of the considered unserviceable states (lacking 1.583 of the quantity of diagnostic information) the set of diagnostic parameters ought to be supplemented. That should be done in the way enabling an unequivocal distinction of these states.

The lacking quantity of diagnostic information about the engine's working spaces technical state (the additional diagnostic parameters) might be obtained from the harmonic analysis of courses of pulsation pressure in the exhaust channel gathered as the result of experimental investigations of the real objects (factual introducing the failures into laboratory engines) as well as the systematic observations of the thermal-flow processes carried out on a large number of examined engines of the same type, without any interferences into their technical condition (the engines operated on warships of the Polish Navy).

\section{Conclusions}

The method presented in this elaboration consists in a diagnostic informativeness estimation of the marine diesel engine measurable gas-dynamic parameters. It enables picking out such a set of parameters which allows a precise qualification of the technical state of structural elements of the engine working spaces. A quantity of diagnostic information has been assigned for the selected diagnostic parameters: pressure, temperature and the exhaust stream velocity in the channel powering the turbocharger. It was done by means of an entropy function. The applied method permitted eliminating the exhaust temperature as the parameter which does not bring enough essential information about the technical state of the engine working spaces.
Brakującą ilość informacji diagnostycznej o stanie technicznym przestrzeni roboczych silnika (dodatkowe parametry diagnostyczne) można uzyskać z analizy harmonicznej przebiegów pulsacji ciśnienia w kanale spalin wylotowych, uzyskanych w wyniku badań eksperymentalnych na obiektach rzeczywistych (z faktycznym wprowadzaniem uszkodzeń do silników laboratoryjnych) oraz systematycznie prowadzonych obserwacji przebiegu procesów cieplno-przepływowych na dużej liczbie badanych obiektów tego samego typu, bez ingerencji w ich stan techniczny (silników eksploatowanych na okrętach MW RP).

\section{Podsumowanie}

Zaprezentowana w opracowaniu metoda oceny informacyjności diagnostycznej mierzalnych parametrów gazodynamicznych pozwala na wytypowanie takiego zbioru parametrów, który pozwoli na precyzyjne określenie stanu technicznego elementów struktury przestrzeni roboczych silnika okrętowego. Ponadto przeprowadzona w opracowaniu analiza informacyjności diagnostycznej wytypowanych parametrów gazodynamicznych (ciśnienia, temperatury i strumienia masy spalin przepływających przez przekrój kontrolny kanału spalin wylotowych silnika okrętowego) pozwoliła na redukcję ich liczby o parametry niedające istotnej informacji o stanie technicznym przestrzeni roboczych silnika (w tym przypadku parametrem takim okazała się temperatura spalin).

Artykut recenzowany

\section{Bibliography/Literatura}

[1] Benjamin J.R., Cornell C.A.: Rachunek prawdopodobieństwa, statystyka matematyczna i teoria decyzji dla inżynierów. WNT, Warszawa 1971.

[2] Hebda M., Niziński S., Pelc H.: Podstawy diagnostyki pojazdów mechanicznych. WKit, Warszawa 1980.

[3] Szczeciński S.: Lotnicze silniki tłokowe. MON, Warszawa 1969.

Mr. Zbigniew Korczewski, DSc., DEng. - professor in the Faculty of Navigation and Naval Weapons at the Polish Naval Academy.

Dr hab. inż. Zbigniew Korczewski prof. AMW-profesor na Wydziale Nawigacji i Uzbrojenia Okrętowego Akademii Marynarki Wojennej.

e-mail: z.korczewski@amw.gdynia.pl
[4] Piaseczny L.: Technologia naprawy okrętowych silników spalinowych. WM, Gdańsk 1992.

[5] Wiśniewski S.: Obciążenia cieplne silników tłokowych. WKiॄ, Warszawa 1972.
Mr. Marcin Zacharewicz, MEng. - assistant in the Faculty of Mechanical and Electrical Engineering at the Polish Naval Academy.

Mgr inż. Marcin Zacharewicz - asystent na Wydziale Mechaniczno-Elektrycznym Akademii Marynarki Wojennej.

e-mail: zacharmar@poczta.fm

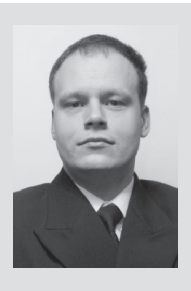

